\title{
Szakmai vezetőknek 1 percben: Orvosi világszervezetek figyelmeztetnek, hogy a keringési betegségek kockázatának szürése nem csökkenti e betegségek terheit, inkább a népesség-szintű elsődleges megelőzés vezethet eredményre ${ }^{1}$
}

\author{
For professional leaders in 1 minute: World medical organizations warn that \\ screening the risk for circulatory diseases does not decrease their burdens; \\ primary prevention at population-level may yield results instead
}

Beküldve: $\quad$ 2020. 08. 23.

doi: $\quad$ 10.24365/ef.v61i3.622

Két neves orvosi világszervezet, a World Stroke Organization (WSO) és a World Heart Federation ${ }^{i}$ (WHF) közös álláspontot fogalmazott meg a keringési betegségek kockázati szűrésének hatásosságával kapcsolatban. Megállapítják, hogy az Inter99 randomizált kontrollált vizsgálat ${ }^{2}$ eredménye, amelyben 59.616 30-60 éves embert 10 éven át követtek, továbbá 15 randomizált kontrollált vizsgálat, összesen 251.891 felnőtt adatainak Cochrane metaanalízisének ${ }^{3}$ eredménye igazolja, hogy a szívés érrendszeri betegségek, valamint azok kockázati tényezőinek szúrése (még kapcsolódó életmódtanácsadással sem, mint az Inter99 vizsgálatban) nincs jelentős hatással az ischaemiás szívbetegség és a stroke előfordulására és a halálozásra.

Nem sikerült kimutatni a szűrés költséghatékonyságát ${ }^{4}$, ugyanakkor találtak bizonyítékot ${ }^{5}$ arra, hogy a szürés növeli az egészségegyenlőtlenséget. A WSO veszélyesnek tartja és beszüntetni javasolja ${ }^{6}$ a szűrés alapján történő alacsony, közepes vagy magas kockázatú csoportba besorolást, mert az esetleges téves biztonságérzet miatt az egyének elhanyagolhatják a kockázatok elkerülését.

Mivel a stroke és a szív-és érrendszeri betegségek hátterében álló okok jól azonosíthatók és ellenőrizhetők, a magas kockázatúak szűrésére alapozott stratégia nem játszik jelentős szerepet e betegségek elsődleges megelőzésében. Ez a stratégia inkább kiegészítő elem lehet a sokkal hatékonyabb népesség-szintû́ megelőzési stratégiában. Sürgősen módosítani kell a stroke és a szív- és érrendszeri betegségek elsődleges megelőzését, elsőbbséget biztosítva az egész népességre kiterjedő elsődleges megelőzési stratégiáknak. ${ }^{3}$

(Kapcsolódó korábbi 1 perces: Szakmai vezetőknek 1 percben: Az ischaemiás szívbetegség elsődleges megelőzése: népesség, egyének, egészségügyi szakemberek)

' Stroke Világszervezet

ii Szív Világszövetsége 


\section{HIVATKOZÁSOK}

\footnotetext{
${ }^{1}$ Goiana-da-Silva F, Cruz-e-Silva D, Lindeman M, Hellman M, Angus C, Karlsson T, Renström M, Ferreira-Borges C. (2019). Implementing the European Action Plan on Alcohol. Lancet Public Health. 2019 Oct;4(10):e493.

doi: 10.1016/S2468-2667(19)30174-4

2 Jørgensen T, Kart Jacobsen R, Toft U, Aadahl M, Glümer C, Pisinger C. Effect of screening and lifestyle counselling on incidence of ischaemic heart disease in general population: Inter99 randomised trial. BMJ 2014; 348: g3617.

${ }^{3}$ Krogsbø|l LT, Jørgensen KJ, Gøtzsche PC. General health checks in adults for reducing morbidity and mortality from disease. Cochrane Database Syst Rev 2019; 1: CD009009.

${ }^{4}$ Lee JT, Lawson KD, Wan Y, et al. Are cardiovascular disease risk assessment and management programmes cost effective? A systematic review of the evidence. Prev Med 2017; 99: 49-57.

${ }^{5}$ Wallach-Kildemoes H, Diderichsen F, Krasnik A, Lange T, Andersen M. Is the high-risk strategy to prevent cardiovascular disease equitable? A pharmacoepidemiological cohort study. BMC Public Health 2012; 12 : 610.

${ }^{6}$ Brainin M, Feigin VL, Norrving B, Martins SCO, Hankey GJ, Hachinski V. Global prevention of stroke and dementia: the WSO Declaration. Lancet Neurol 2020; 19: 487-88.
} 